\title{
LA COMPRENSIÓ DE LA CRONOLOGIA A FINALS DE L'EGB
}

\section{Rosa Maria Puertas Moreno. Alumna de 3r. curs de l'Ensenyament de Mestre en Educació Musical. Tarragona.}

\section{Introducció i finalitats del treball}

El propòsit inicial d'aquest treball és comprovar fins a quin punt els alumnes, en finalitzar l'antiga EGB, tenen assolides unes idees bàsiques sobre cronologia i/ o èpoques històriques estudiades amb anterioritat. Val a dir que aquest treball s'ha fet a l'assignatura d'Història Local i Comarcal, impartida pel professor Antoni Gavaldà, el curs 1995-96. Per a l'estudi s'ha comptat amb els resultats obtinguts en un treball semblant (POZO, 1985) que ha servit de base orientativa.

L'estudi ha constat d'una enquesta que s'ha passat a una mostra de 66 alumnes de 8è curs d'EGB pertanyents a un centre privat concertat de la ciutat de Tarragona. L'enquesta s'ha proposat en set qüestions diferenciades i relacionades amb el tema -la cronologia i el temps històricon es demanava als enquestats un raonament o explicació a la resposta donada, cosa que ens ha servit per veure si entenien el que se'ls preguntava i si eren capaços de relacionar-ho amb coneixements previs o amb la temàtica que en aquell moment treballaven. Cal indicar que totes les dades presents al formulari estaven extretes del llibre de text que els alumnes havien fet servir el curs anterior.

\section{Anàlisi dels resultats}

A continuació passem a analitzar els resultats amb les preguntes incloses a l'esmentat qüestionari, inserides en lletra cursiva i en tramat:

A/segle XV es comencen els grans descobriments oceànics i les conquestes d'aquests territoris. Aquí tens alguns exemples:

- 1488: arribada a l'África meridional

- 1498: arribada a l'Índia

- 1513: descoberta de l'oceà Pacífic

- 1519: inici de la primera volta al món

Quins d'aquests fets tenen lloc durant el lustre següent al descobriment d'Amèrica? Per què?

Dintre d'aquesta qüestió apareixien dos aspectes: el significat de la paraula lustre i l'any del descobriment d'Amèrica. El concepte de lustre com a mesura de temps -període de cinc anys- no va ser assolit per cap alumne, si bé la data del descobriment d'Amèrica va ser sabuda per alguns -ho expliciten 8 enquestats (12\%).

La pràctica totalitat dels alumnes va fer cas omís de la paraula lustre, d'aquí que les respostes hagin estat força variades -des dels que diuen quins són els fets posteriors al 1492 fins als que donen el fets que, al seu parer, influencien de manera directa en el descobriment d'Amèrica-, comptabilitzant-se'n, en total, 12 de diferents. Les dues respostes més rellevants digueren:

- L'arribada a l'Índia, apuntada per 20 alumnes (30\% del total). Les raons donades són diverses, des dels que pensen que dels fets posteriors al 1492 és el més proper, o l'únic pertanyent al segle XV, fins als que diuen que Colom volia anar a les Índies, passant pels qui pensen que és un fet anterior al descobriment d'Amèrica, cosa que demostra el desconeixement de la data.

- La volta al món -triada per 13 alumnes (quasi el $20 \%$ )-, creuen que el fet està relacionat amb la descoberta feta per Colom perquè és durant la volta al món que es descobreix Amèrica o perquè, en descobrir Amèrica, Colom fa augmentar l'interès per descobrir altres indrets, cosa que provoca l'inici de la volta al món. És força indicatiu que quasi la meitat dels que han triat aquesta resposta pensen que la volta al món és anterior al descobriment d'Amèrica.

Entre l'excomunió del religiós alemany Martí Luter el $1517 \mathrm{i}$ el Concili de Trento el 1554 hi ha 37 anys.

$A$ quants quinquennis correspon aquesta diferència d'anys? Raona la teva resposta.

En aquesta pregunta també hi havia dues qüestions incloses: a quin període de temps correspon un quinquenni, i si aquests es mesuren amb nombres enters o poden ser decimals.

La percepció de quinquenni com a període de temps és força assolida. Cal remarcar, però, que més de la meitat dels alumnes $(51,5 \%)$ no han donat resposta a aquesta pregunta.

Dels que han contestat, $12(18 \%$ del total dels 


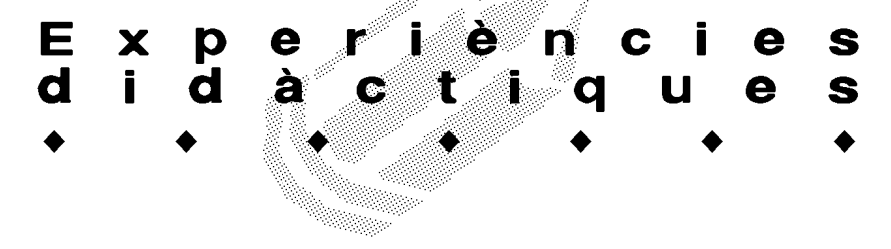

enquestats) pensen que quinquenni és un període de cinc anys; 17 (25,7\% del total) que és de 15 anys, i una persona pensa que correspon a 500 anys.

Pel que fa a la concepció del període de temps com a unitats -és a dir, no poden ser cinc quinquennis i mig, per exemple-, el 33,3\% dels alumnes (22) té, o sembla tenir, la noció clara, mentre que el 21,2\% (14 estudiants) pensen que els períodes de temps no tenen per què mesurar-se amb nombres naturals, i que poden ser decimals.

Les principals institucions catalanes, les Corts i la Generalitat, van sorgir durant e/s. XIII i van ser abolides després de la Guerra de Successió, el 1714. Quants segles sencers van funcionar? Explica el perquè.

Amb aquesta pregunta s'intentava veure si els alumnes eren capaços de relacionar un segle amb un any, i trobar la diferència. El que s'esperava era que passessin l'any (1714) a segles, o bé a l'inrevés, el segle (XIII) a un any aproximat. Vora el $42 \%$ ho sap fer -28 alumnes-, tot $i$ que alguns han pogut donar un raonament incorrecte, o han fet malament el càlcul.

La resposta més nombrosa -vora el 38\% (25 alumnes)- és la correcta: 5 segles. Els alumnes ho han esbrinat de les dues maneres que esmentàvem abans.

La segona resposta més contestada ha estat la de 4 segles $-21,2 \%$ (14 alumnes)-. Ho han fet bàsicament per dues raons: considerant el 1714 com a segle XVII o, com que se'ls demanava per segles sencers, menyspreant els segles XIII i XVIII.

La Guerra dels Segadors comença el 1640 amb el Corpus de Sang i acaba el decenni següent amb el Tractat dels Pirineus. Quin any es va signar aquesta pau, el 1649 o el 1659? Raona la teva resposta.

En aquesta qüestió també es demanava per un període de temps, ara el decenni.

Menys de la meitat dels enquestats -quasi el $47 \%$ (31 alumnes)- sap o explicita que decenni correspon a un període de deu anys, tot i que a l'hora de donar el raonament aquest no sigui coherent amb la resposta.

De les dues opcions que se'ls proposava, la més apuntada $-45,4 \%$ (30 alumnes)- no és la correcta. En considerar que la data és la del 1649 donen dues raons bàsiques: que una guerra no pot durar 19 anys i que la data que més s'aproxima als 10 anys és aquesta.

La segona opció, el 1659, la correcta, únicament l'han triat 19 alumnes -no arriba al 30\%-. Les respostes també han estat força curioses: perquè una guerra no pot durar només 9 anys i perquè han de passar més de 10 anys.
Finalment quatre alumnes han donat a entendre que, perquè sigui el decenni següent al 1640 , la data ha de pertànyer als anys 50 , és a dir, del total d'alumnes únicament el $6 \%$ té clar el concepte que es demanava.

Nosaltres considerem que l'era actual comença amb el naixement de Jesucrist, però els musulmans no.

Per a ells comença amb l'hègira -quan Mahoma marxa cap a La Meca-que és l'any 622 de la nostra era. L'any 1996, quin any és per a ells? Com ho has fet per saber-ho?

Aquí el que es pretenia era saber si els alumnes tenien assolit el concepte d'eres paral.leles. El 68,2\% dels alumnes (45) han donat la resposta correcta, el raonament també ho era, restaven al nostre any actual, el 1996, els 622 anys de diferència entre les dues eres.

Alguns alumnes han matisat el seu raonament i han demostrat no tenir clar el concepte del paral-lelisme d'ambdues eres amb respostes com: "ells comencen el 622 i nosaltres el 0", "són 622 anys abans del naixement de Jesucrist", "quan nosaltres comencem a comptar ells encara han d'esperar 622 anys", "ells encara estan al 622", etc.

Tot i que quantitativament no és rellevant, sorprenen aquells que han sumat les dues xifres. Tanmateix, és major el percentatge dels que pensen que l'era musulmana es correspon amb la mateixa era, el mateix any o el mateix segle nostre -5 alumnes-.

Vora el 1450 l'alemany Gutemberg va inventar la impremta. A quin segle es va produir aquest avenç? Raona la teva resposta.

Novament incidíem en el concepte any-segle. Tot i que 58 dels 66 -quasi el $88 \%$-han donat la resposta correcta, d'aquests, $16(27,6 \%)$ demostren que no saben el perquè, o bé no el diuen, o bé donen un raonament incorrecte. L'altre $72,4 \%$ restant aconsegueix saber el segle sumant un a les dues primeres xifres de l'any, és a dir, han fet: $14+1=15$ $i$ han donat com a resposta correcta el segle XV.

Els dos moviments històrics, cristians i de pensament que citem a continuació es donen des del segle XV fins el XVIII: protestantisme-II.lustració.

Ordena's cronològicament i digues a quin segle corresponen. Per què has donat aquesta resposta?

Amb aquesta última pregunta es volia comprovar fins a quin punt els alumnes tenien mínimament clars dos conceptes històrics estudiats prèviament. Cap alumne ha 


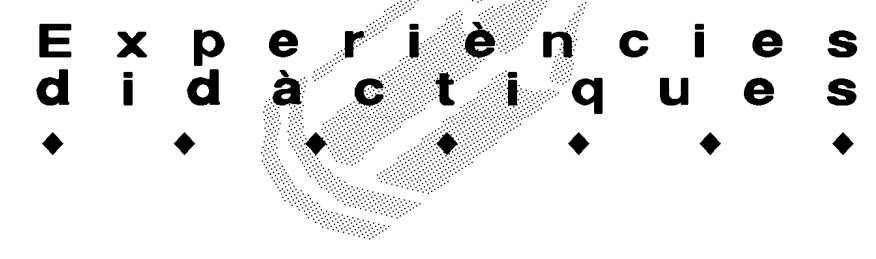

estat capaç de fer-ho correctament, i la majoria ni tan sols s'hi ha sabut aproximar.

Dels 66 alumnes 21 no han contestat (suposa el $31,8 \%), 28(42,4 \%)$ pensen que la II.lustració és un fet anterior al protestantisme, i $16(24,2 \%)$ que és posterior. L'estudiant que ens falta per tenir les 66 respostes ha contestat: "any i mig per cadascun", per tant no se l'ha inclòs en cap dels altres grups.

Dels que pensen que la II.Justració és anterior al protestantisme, 15 (53,6\%) lliga la II.lustració amb idees i major coneixement del poble, que, segons el seu parer, provoca que la gent pugui estar en "condicions de protestar".

Dels que pensen que la II-lustració és posterior (5), saben que al segle XVIII es produeix la Revolució Francesai sorgeixen els illustrats, però no donen cap altre tipus de raonament; i 6 pensen que amb la II.lustració (s. XVIII) sorgeixen les idees necessàries per solucionar les protestes.

$\mathrm{Si}$ ja hem vist com aproximadament no arriba a una quarta part dels enquestats els que saben el segle que correspon a la II.Justració -és el que estaven estudiant en el moment de passar l'enquesta-, pel que fa a la situació del protestantisme el fet és rellevant, ja que únicament una persona el situa correctament al segle XVI i 13 al segle XV. Com que se'ls deia que els dos fets passaven entre els segles XV i el XVIII possiblement han pensat que un era al $X V$ i l'altre al XVIII.

\section{Conclusions}

En primer lloc caldria destacar que els alumnes amb els quals hem incidit, en finalitzar l'EGB, no tenen clares les idees sobre conceptes referits a períodes de temps com ara lustre, quinquenni, decenni, segle, etc (essent aquest últim el que en principi sembla que tenen més assolit); per tant, i basant-nos en la terminologia emprada per Pozo, podem afirmar que els adolescents d'aproximadament 12 anys tenen una "estructuració temporal incorrecta".

Evolutivament fins a l'adolescència els alumnes no comencen a adonar-se del caràcter convencional de les unitats de mesura de temps. Molts veuen aquesta convencionalitat i la tenen clara, però la seva comprensió és més tardana, per això quan se'ls demana com fan per saber a quin segle pertany un any no saben donar resposta -la dificultat dels alumnes estava en la necessitat de coordinar dades en unitats diferents (POZO, 1985). Es pot afirmar que a l'adolescència encara és present el desconeixement de la continuïtat temporal: "El conocimiento de las fechas no siempre implica un entendimiento de su significado" (POZO, 1985).

En segon lloc caldria destacar que de l'estudi realitzat es desprèn que els alumnes adolescents no tenen idees clares sobre els fets històrics estudiats, ni aspectes com la successió, la causa i la continuïtat temporal. Els alumnes no són capaços de lligar diferents conceptes com ara: el protestantisme amb Martí Luter o el Concili de Trento, o la II.lustració amb la Revolució Francesa. Possiblement, i segons l'autor referenciat, perquè no comprenen els motius que porten al desenvolupament d'un fet. Tanmateix tampoc no tenen totalment clar el concepte de paral-Jelisme entre diferents eres, ja que els adolescents de 12-13 anys pensen que l'era musulmana és un període intermedi entre l'era aC i la dC; a més aquí contribueix la idea generalitzada per part dels occidentals que la civilització musulmana es troba més endarrerida tecnològicament, per la qual cosa alguns alumnes pensen que és anterior en el temps: confusió temps-fets succeïts.

Topem aquí també amb un problema: l'abstracció. A l'escola sovint es donen per sabuts i entesos conceptes que no ho estan; per això caldria tenir molt més present un estudi evolutiu, tant a l'hora d'explicar qualsevol matèria (per part del mestre), com a l'hora de fer els llibres de text (per part de les diferents editorials).

La manca de comprensió dels elements fonamentals de la Història, demostrada a l'estudi analitzat, són bàsicament dos: la disposició dels programes d'estudi cronològicament (quan els alumnes tenen molt limitada la seva estructuració temporal, sempre segons les edats), i l'abundància de conceptes i termes incomprensibles pels nens als llibres de text.

Si bé l'alumne està capacitat per memoritzar dates, fets i noms, intel-lectualment no ho està per comprendre els significats (a més cal afegir que tampoc no se l'ha educat en aquest sentit). La funció de l'ensenyament hauria de ser: "favorecer el avance cognitivo del alumno en este área", remarcant, a més, que "el nivel cognitivo del alumno debe considerarse como una barrera que hay que superar, partiendo de sus posibilidades reales" (POZO, 1985).

Seria bo acabar amb dues frases de l'autor que serveixen de conclusió a tot el que s'ha estat intentant exposar i que ens haurien de fer reflexionar:

"Hoy por hoy, la gran mayoría de los alumnos adolescentes no están intelectualmente capacitados para comprender la historia que se les pretende enseñar", i també que: "El nivel de desarrollo intelectual de un alumno determina lo que ese alumno es capaz de aprender o comprender".

\section{Referències bibliogràfiques}

POZO, I. El niño y la historia. Servicio de Publicaciones del MEC. Madrid. 1985. 